\title{
Comparative Analysis of Teaching Effectiveness between Licensed and Normal Trained Teachers in Tanzania
}

\author{
Benjamin Mbeba Meli \\ Dares Salaam University College of Education \\ Faculty of Humanities and Social sciences, \\ Department of History, political Science and Development Studies \\ P.O. Box 2329 Dares Salaam Tanzania, East Africa \\ Email: benjaminmbeba@gmail.com
}

\begin{abstract}
This paper utilizes data from a study that sought to compare teaching effectiveness between licensed and normal trained teachers in Tanzania. The study employed a descriptive research design and a theoretical framework of 5Es of Instructional model of teaching and learning. Data were collected from the field in two phases. In the first phase, qualitative data were collected on how licensed and normal trained teachers were able to prepare; schemes of work, lesson plans, lesson notes, teaching/ learning materials and curriculum, mastery of the subject and language use, marking students' assignments, classroom management skills, methods of teaching and teacher personality. Second phase of data collection focused on quantifying some variables on important issues that arose during focus group discussions and key informant interviews. It is recommended that; the Ministry of Education, Science and Technology (MoEST) should provide enough funds for teaching and learning materials, and support the existing Teachers Resource Centres (TRC) so that there are regular and continuous in-service activities going on at the centres to equip teachers with more knowledge and skills. Zonal and District Secondary Schools Inspectorate officers should conduct frequent schools inspections in order to monitor the teachers in their day to day activities. School head masters/mistresses should see to it that daily routine of the teachers is monitored and that local arrangements are made for teachers to share knowledge and skills of teachers' behaviour among themselves, and, Tanzania Institute of Education (TIE ) should ensure that schools curricula are in operation for a long time before changing them.
\end{abstract}

Key words: Licensed and Normal trained teachers, teaching effectiveness, Block Teaching

DOI: $10.7176 /$ RHSS/10-6-10

Publication date:March $31^{\text {st }} 2020$

\subsection{Introduction}

Teacher education and training in any country is always at the centre of policy discussions about human development. It occupies a central role in determination of individual living standards as well as the welfare of nations. To cope with new and rapidly changing conditions in an increasingly interdependent world economy, those who receive good educational training are likely to access, interpret and utilize massive available information for problem-solving together with improving their living standards. To that effect, it requires a higher quality of good teacher training mode that provides young people and adults with knowledge including appropriate professional skills in order, to function effectively in the new educational environment.

Tanzania has concentrated on maximizing enrolment in secondary schools. The trend is clearly reflected in the numbers of registered secondary schools in the years between 2006 and 2008 (URT, 2001-2008). The target has been to increase the Gross Enrolment Ratio (GER) from 5\% in 2006 to 12\% in 2008 (URT, 2001-2007). In keeping with efforts of expanding secondary school education in Tanzania, the Ministry of Education, Science and Technology (MoEST) through the Tanzania Institute of Education (TIE), designed a curriculum for a two years diploma in education program, which divided the curriculum into two categories that is professional and academic studies. The professional studies included subjects like Educational Psychology and Counselling, Foundations of Education; Educational Research, Measurement, Evaluation, Curriculum and Teaching. Each of these subjects had one hour of teaching per week. The academic study involved subjects like Information Communication and Technology (ICT); Educational Media and Technology; Communication skills; Teaching Methods; Religion and Development Studies. Each academic subject had two hours per week (MoEST, 2004). In the year 2002 and thereafter, abolition of fees in primary schools increased the numbers of students in primary schools. This measure put an immense pressure on secondary schools. Thus, there arose a need to increase secondary schools so as to keep pace with the increasing numbers of students from standard seven who vie to join secondary schools. The move where the Highly Indebted Poor Countries (HIPC) were exempted from paying their debts provided a leeway for Tanzania to use tha money that would have settled the debt to improve social services, transport and communication infrastructures. This, in turn, enabled and empowered the Tanzania government to construct a lot 
of secondary schools which again demanded recruitment of more teachers to bridge the gap. This resulted in a crisis of shortage of teachers.

In order to solve the acute shortage of teachers, MoEST through its agency Tanzania Institute of Education, designed yet another curriculum for licensed teachers' program known as Induction Course for Licensed Secondary School Teachers, which was taught for three months. The curriculum was divided into four modules as follows: Module one: Teaching and Learning; Module two: The Teacher and Teaching Profession; Module three: Adolescence and Schooling; and Module four: School Organization and Management (MoEST, 2004).

\subsection{Views on Teaching Effectiveness}

Teaching effectiveness is defined differently in the context of simplistic and mechanistic forms. Firstly, it is viewed as the ability of imparting knowledge to a learner or using archaism that a "learned" person "learns" his/ her pupil/student (Campbell et al., 2004). Secondly, it is defined as a dynamic and complex teacher to student' subjects matter and interaction process in which it is viewed as creation of proper environment for teaching and learning (Jones et al., 2006). Such environment should ensure respect for student's intellectual integrity and capacity for independent judgement and therefore, teaching effectiveness is inevitably an inter- personal activity involving systematic activities aimed at changing an individual's cognitive and psychomotor behaviour. Studies by Good and Brophy (2003), Petty (2006) and Stronge (2007) have typically identified some characteristics of teaching effectiveness to any particular teacher, that should have;

- Command of theoretical knowledge about learning including behaviour

- Display of attitudes that foster learning as well as genuine human relationships

- Command of knowledge in the subject matter to be taught

- Control of technical skills of teaching and learning

- Clarity of teacher's explanation and direction

- Establishment of a task-oriented classroom climate

- A variety of learning activities

- Establishment and maintenance of momentum and pace for the lesson

- Encouragement of pupil participation and getting all pupils involved

- Delivery of a well-structured and well-organized lesson

- Monitoring of pupils' progress and attending quickly to pupils' needs

- Provision to pupils with positive and constructive feedback

- Ensuring of coverage of the educational objectives; and making good use of the questioning techniques.

\subsection{Contrasting Theoretical Strands on Teaching Effectiveness between Licensed and Normal Trained} teachers

Literature review reveals a non-conclusive debate regarding the threats and opportunities of licensed trained teachers who were recruited during the crash program in Tanzania. Some peole especially politicians and few academics $i$ hold the view that recruitment of licensed trained teachers in Tanzania to a large extent boosted education sector in Tanzania. They argue that the licensed trained teachers were recruited by the government in order to solve the acute shortage of teachers (MoEST, 2004). Meli (2004: pg?) noted that:

"....... a good teacher does not necessarily have to be one who stays in the classroom

for a long period of training, rather it is the matter of individual commitment

and background, motivation, working environment and political support........"

This theoretical strand posits that the benefits of licensed trained teachers for one way or another were acted as the solutions of education problems in Tanzania. The second theoretical strand perceives that licensed trained teachers posed more educational threats to education standards. These teachers were considered to be the causal factor for deterioration of the quality of education in Tanzania (Galabawa et al., 2000; Mussika, 2002). The main arguments advanced here are that, the massive teachers trainees' enrolment, modes of teachers' training adopted by the government and category of teachers selected to join in crash program to a large extent led to the deterioration of teaching effectiveness. They went further that licensed trained teachers were worse in teaching effectively than normal trained teachers because they lacked intellectual techniques, short period of specialized training was limited compared to normal trained teachers who spent/ spend a long period of training of two years course. In supporting that argument, Liberman (1956) argues that entry into the teaching profession is usually required a long period of preparation, and no one could employ a physician who attended a short course in medicine and regard him / her as a physician. Due to the above educational theoretical strands on teaching effectiveness between these two types of teachers, this paper tries to establish the relevant theoretical strand as far as education in Tanzania is concerned. 


\subsection{Teacher Appraisal between Licensed and Normal Trained Teachers}

One of the important teaching effectiveness developments among teachers is the use of teacher appraisal (Middlewood and Cardno, 2001; Jones et al., 2006) ). Self appraisal and critical reflection by teachers on their teaching effectiveness are important aspects of their ability to continue to improve and develop the quality of their teaching. Pollard et al, (2008) describe "reflective teaching" as the adoption by teachers of constant self-appraisal in which they monitor, evaluate and revise their own practice in a cyclical manner. They argue that adopting this stance requires an open-minded willingness to look at aims and consequences, to engage with colleges and externally developed frameworks, and consider different sources of evidence (Ibid). Therefore, teachers should prepare typical questions asked in such self- appraisal as follows;

- Do I plan the lesson well with clear aims and a suitable lesson, content and structure?

- Do I prepare the materials needed for the lesson, such as worksheets and apparatus in good time?

- Are my explanations and instructions clear and pitched at the right level for pupils to understand classroom well and use both open and closed questions?

- Do I use a variety of learning outcomes?

- Are my lessons suitable for the range of ability of the pupils teach (able, average and less able)?

- Do I maintain a level of control and order that is conducive for learning to occur ?

- Do I monitor pupils' learning closely during the lesson and give help to those having difficulties

- Do I mark work, including home work, thoroughly, constructively and in a good time?

- Do I have good relationships with pupils based on mutual respect and rapport? And is my subject expertise fine for the work I do?

All these self-teacher appraisal questions are vital in evaluating the teaching effectiveness to both types of teachers. Thus from the above arguments, this paper intends to compare teaching effectiveness between licensed and normal trained teachers in secondary schools and to propose the type of teachers that is suitable for teaching development in Tanzanian context.

\subsection{The Description of the Study Areas}

The study was conducted in four municipals in Tanzania namely: Morogoro, Iringa, Songea and Bunda. Reasons for selecting those areas were: first, they had teacher training colleges which offered both crash and normal teacher training programs. Therefore, it was likely that some of the licensed trained teachers were posted to schools within those particular areas. Second, it might have been convenient for the researcher because schools and colleges were close to each other, so it was easy for the researcher to move from where knowledge was given to where practice was done.

\subsection{Methodology}

Primary data were collected using both qualitative and quantitative methods, where secondary data obtained from literature search and review of relevant official documents. The literature review further highlighted contrasting theoretical strands on teaching effectiveness between licensed and normal trained teachers, concept of teaching effectiveness and teacher appraisal between licensed and normal trained teachers. The sample of the study comprised of 200 respondents by using purposive sampling and snow-bow technique. The study also employed a descriptive research design and a theoretical framework of 5Es of Instructional model of teaching and learning as developed by Trownbridge and Bybee (1996). Two phases of data collection and analysis were conducted. In the first phase, qualitative data was collected based on how licensed and normal trained teachers were able to prepare schemes of work, lesson plans, lesson notes, teaching/ learning materials, the curriculum, mastery of the subject and language use, marking student's assignments, classroom management skills, methods of teaching and teacher personality. The second phase of data collection was focused on quantifying some variables on important issues discussed during focus group discussion, observation and key informant interviews.

\subsection{Findings of the Study}

The findings of the study are presented under the following sub-sections: demographic and socio-economic characteristics of the respondents, schemes of work, lesson plans, lesson notes, teaching and learning materials, and mastery of the subject and language use, marking students' assignments, classroom management skills, and methods of teaching and teacher personality.

\subsection{Demographic and Socio-economic Characteristics of the Respondents}

The study was important to find out the demographic and socio-economic characteristics of the respondents that were involved in the study by looking on main variables like age, sex and levels of education. It was believed that those variables would provide the right indication if at all there was a differences or similarities of teaching effectiveness between licensed and normal trained teachers. The distribution of the respondents in terms of sex, 
age and level of education is presented in Table 1.

Table 1: Demographic and Socio-economic Characteristics of the Respondents

\begin{tabular}{|c|c|c|c|c|c|c|c|c|c|c|c|}
\hline \multirow{2}{*}{$\begin{array}{l}\text { Respondents' } \\
\text { Name }\end{array}$} & \multicolumn{2}{|l|}{ Sex } & \multicolumn{4}{|c|}{ Age } & \multicolumn{5}{|c|}{ Level of Education } \\
\hline & $\frac{0}{\sum}$ & 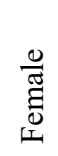 & 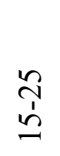 & $\stackrel{n}{\mathfrak{c}}$ & 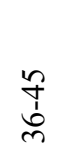 & $\begin{array}{l}n \\
n \\
b \\
y\end{array}$ & 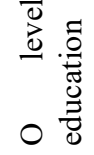 & 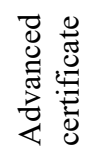 & $\frac{\overparen{\Xi}}{\frac{0}{0}}$ & 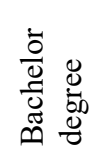 & 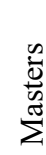 \\
\hline Headmasters & 12 & - & - & - & 8 & 4 & - & - & 9 & 3 & - \\
\hline Headmistress & - & - & - & - & - & - & - & - & - & - & - \\
\hline $\begin{array}{l}\text { Normal } \\
\text { trained } \\
\text { teachers }\end{array}$ & 16 & 14 & - & 5 & 22 & 3 & - & - & 23 & 7 & - \\
\hline $\begin{array}{l}\text { Licensed } \\
\text { trained } \\
\text { teachers }\end{array}$ & 24 & 6 & - & 28 & - & - & - & 30 & - & - & - \\
\hline Students & 30 & 30 & 60 & & & & 60 & - & - & - & - \\
\hline $\begin{array}{l}\text { Students' } \\
\text { parents }\end{array}$ & 16 & 8 & - & - & 8 & 6 & - & 5 & 12 & 7 & - \\
\hline Tutors & 20 & 12 & - & - & 3 & 29 & - & - & - & 23 & 9 \\
\hline $\begin{array}{l}\text { Municipal } \\
\text { officials }\end{array}$ & 2 & 2 & - & 2 & 2 & & - & - & - & 2 & 2 \\
\hline $\begin{array}{l}\text { MoEVT } \\
\text { officials }\end{array}$ & 1 & 1 & - & 1 & 1 & & - & - & - & 1 & 1 \\
\hline TIE officials & 1 & 1 & - & - & 1 & 1 & - & - & - & 1 & 1 \\
\hline $\begin{array}{l}\text { Zonal } \\
\text { secondary } \\
\text { school } \\
\text { inspectorate } \\
\text { officers }\end{array}$ & 2 & 2 & - & - & 2 & 2 & - & - & - & 1 & 3 \\
\hline Total & 124 & 76 & 60 & 36 & 47 & 45 & 60 & 35 & 44 & 45 & 16 \\
\hline
\end{tabular}

Source: Computed from field data (2014)

The data displayed in Table 1 shows that out 200 respondents involved in the study, 124 (67\%) were male while $76(33 \%)$ were female. Among the respondents, $36(18 \%)$ were in 26-35 the age group. $47(23.5 \%)$ were in the 3645 age group and $45(22.5 \%)$ were in the $46-55$ age group. In this regards, the table revealed that men were more than female and it was found that, most of the respondents who provided their opinions about teaching effectiveness between licensed and normal trained teachers were at the age of 26-55 years. This showed that the respondents were matured enough and they had enough working experience. Since it is believed that education is the key of human life, the respondents were asked about their level of education. Table 1 shows that out of 200 respondents interviewed on their level of education, 60 (30\%) were ordinary level, $35(17 \%)$ were form six leavers, $44(22 \%)$ had diploma in education. Also $45(22.5 \%)$ were bachelor degree holders and $16(8 \%)$ were masters holders. This revealed that their opinions were relevant to what was going as regards to teaching effectiveness between these two types of teachers.

\subsubsection{Teachers' Preparation on Schemes of Work}

Hoy and Miskel ((1991) stress out that a professional teacher has to show his/her competence skills in practical activities of his/ her areas of specialization on how he/ she is able to prepare well a detailed scheme of work properly. They go further by saying that a well-trained teacher is basically be able to apply both theory and practical activities and failing to apply both results to incompetent teacher (Ibid),

The study revealed that all 30 licensed trained teachers interviewed had their schemes of work missing some important components of teaching skills such as indications of competence and assessments compared to normal trained teachers whose their schemes of work were well prepared. All 12 headmasters/mistresses interviewed showed that normal trained teachers had better schemes of work than licensed trained teachers because they had enough time of studying during their training program. Furthermore, the researcher asked all 30 observed licensed 
trained teachers why their schemes of work lacked the aspects of competence and assessments as compared to normal teachers practice, their response was:

"...during our induction course, tutors taught us only eleven components of the scheme of work. It is no wonder that, competence and assessment aspects are not practiced as these two aspects in question were not part and parcel of the format for the preparation of schemes of work in this respect..."

Those arguments showed that the licensed trained teachers had missed some important aspects of facilitating teaching and learning. For example, on competence level, where the teacher is expected to show skills, knowledge and attitudes which the learners are expected to achieve after completing a particular topic. On assessments, teachers are supposed to show some questions that could assist in assessing the learner's achievements after covering any given specific objectives. It appears that such teaching skills were not imparted to licensed trained teachers. From these findings, it could be concluded that normal trained teachers were better than licensed teachers in terms of schemes of work preparation because their schemes of work had all the required components which would enable them to teach students effectively. The reason behind these differences in schemes of work preparation lied on duration of teacher training. It was found in the study that licensed trained teachers spent only three months in the colleges while normal trained teachers spent two years in the colleges and all the time they were doing continuous assessments and Block Teaching Practice (BTP).

\subsubsection{Teachers' Preparation on Lesson Notes}

Important characteristics of good lesson notes for the teachers should have the following; an introduction, main body, summary and a list of reference books (Sahlberg, 2003). Furthermore, the lesson notes should be short and clear, up to the point; and legible. They should have a reasonable spacing; should be arranged in a manner that allows easy finding of each step; should be well written and arranged in such a way that points can be read at quick glances; and should indicate the context of the lesson. The study established that the preparation of lesson notes between licensed and normal trained teachers varied for a number of ways. The licensed trained teachers had lesson notes which were too long and not clear and lacked introduction and main body compared to normal trained teachers where their lesson notes were clearly prepared to enable students to write in their exercise books correctly. 34 $(50 \%)$ out of 60 interviewed students went further by pointing out that:

"....teachers are telling us to write lesson notes from our own text books. They do not prepare lesson notes for us; they sometimes select one among us to write lesson notes on the blackboard for us to copy..."

From the most held view as pointed above, it is noted that licensed trained teachers were ill-trained. Getting the pedagogical skills remains a challenge not only to the Tanzania Institute of Education but also the MoEST which is the supervisor of education system in Tanzania.

5.2.3 Differences in Lesson Plans preparation A qualified teacher is expected to be an expert in his/her subject areas and one who has undergone some training beyond the level he/she is expected to teach effectively because teaching and learning is an interactive and continuous process between a learner and a teacher towards a targeted topic or content.

The process of becoming a professional teacher is a lifelong process, which involves years of acquiring knowledge on teaching and learning, trying out new teaching styles that engage learners, observing others, effective use of teaching aids and ability to prepare well-written lesson plans (Clandinin, 1995). Furthermore, Mussika (2002) maintains that when a teacher has a well prepared lesson plan he/she is likely to impart good pedagogical skills to the learners and he (ibid) goes further by stressing out that a poor lesson plan is always resulting in poor learners' achievements. In this regards, the study revealed that licensed trained teachers had ill prepared lesson plans compared to normal trained teachers whose lesson plans were well prepared. All 30 licensed trained teachers that were involved in the study had lesson plans that were not well prepared. The prepared lesson plans had mistakes in all important aspects of a lesson plan such as the stages of lesson development, general and specific objectives as well as teacher's evaluation of the lesson. On other hand, all 30 normal trained teachers that were interviewed had their lesson plans were well prepared.

\subsubsection{Teachers' preparation in Teaching/ Learning Materials and Curriculum Development}

Teaching materials are key ingredients in making teachers' competence. They provide information, organize the presentation of information in terms of scope and sequence and provide teachers with opportunities to use what they have planned before. Teaching materials that are known to enhance teachers' achievement are textbooks, teaches' guides, reference books, and other software and hardware materials like chalkboard, classroom charts and maps (Mussika, 2002). 
Osaki (1996) still maintains that curriculum as a part of pedagogy must be taught carefully to teachers in order to make them competent enough in teaching. He argues that curriculum process is cyclic and it involves activities like situational analysis, methods, organization of learning opportunities and assessment of strategies all of which are interrelated and interdependent factors for teachers' effectiveness in secondary schools (Ibid). The curriculum is at the centre of the education process for it is through the process of effective development, implementation and evaluation of the curriculum that the education aims, goals and objectives are achieved. Curriculum includes systematic and planned teaching and learning experiences provided under the guidance of existing educational institutions. The process of curriculum development involves four basic elements: the learner, the teacher, the content and intended learning outcomes to meet society aspirations (Osaki, 1996).

In consonant with the above observations, it was noted in this study that the uses of teaching/ learning materials and curriculum development were rare. Observations carried out on both licensed and normal trained teachers teaching English and History subjects in Form Two showed that 21 out of 30 licensed trained teachers rarely used teaching and learning materials compared to normal trained teachers who used frequently teaching/learning materials. This made students get bored, less active and doze off. Only 9 out of 30 observed licensed trained teachers used frequently their teaching and learning materials. The study also revealed that 23 out of 30 normal trained teachers observed used frequently teaching and learning materials in their classrooms except 07 out of 30 found were not applying teaching and learning materials. Furthermore, 10 out of 12 headmasters/mistresses commented that normal trained teachers used more teaching and learning materials than licensed trained teachers and the rest 2 out 12 headmasters/mistresses pointed out that licensed trained teachers applied teaching and learning materials. For example, one of the headmasters /mistresses interviewed commented that:

....for many years licensed trained teachers have been teaching students without teaching materials because they were not provided with enough time to prepare teaching and learning materials during their training period.....

In addition, the zonal secondary schools inspectorate reports showed that normal trained teachers used more teaching and learning materials than licensed trained teachers. Figure 1 below summarizes the uses of teaching and learning materials for both licensed and normal trained teachers.

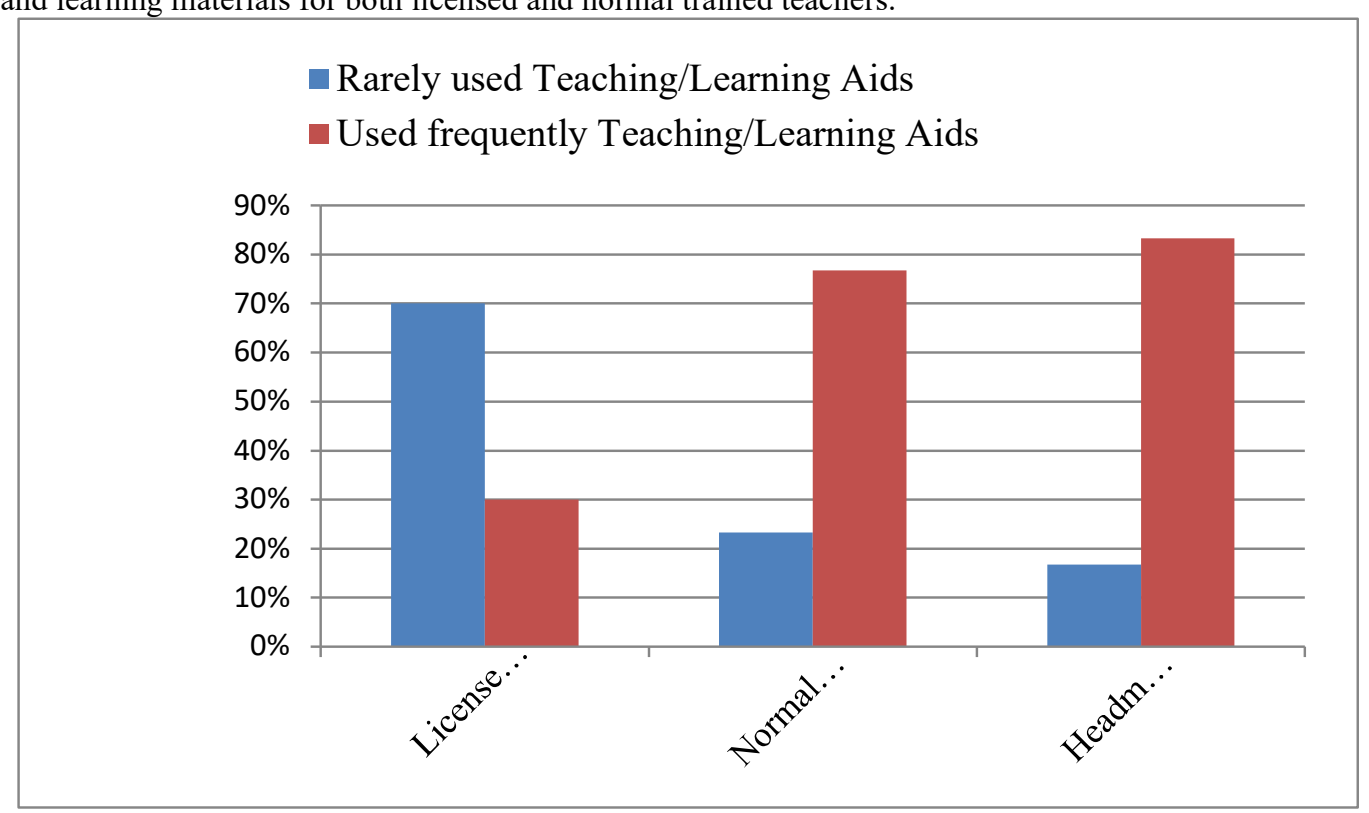

Figure 1: Zonal secondary schools inspectorate, headmasters/mistresses, Licensed and Normal Trained Teachers' Views towards the Use of Teaching and Learning Materials in Classrooms

\subsubsection{Mastery of Subject and Language Use}

Direct observations were made on both types of teachers in the classrooms when teaching same subjects: English language (Form Three) and Kiswahili (Form Three). The aim was to see the similarities or differences in how lesson taught was evaluated. The findings revealed that all 30 licensed trained teachers and normal trained teachers had mastered very well the Kiswahili subject. But the problem was with the English language lessons where it was found out that 23 out of 30 licensed trained teachers were not competently using English as a medium of instruction compared to the normal trained teachers. However, it was noted from 10 out of 12 headmasters / mistresses that 
their licensed trained teachers tend to mix English and Kiswahili during lessons, a move that tend to create confusion among their students.

The findings support the views found in the Eastern Zone Secondary Schools Reports (2008-2010) which showed that during the English lessons, licensed trained teachers and students used Kiswahili language in their discussions. This indicated that licensed trained teachers mastery of the English language was a major problem in teaching their lessons and therefore they were less effective as pointed out by Ogunniyi (1996) and Hudgins (1971) that mastery of language of instruction plays a crucial role to teachers because it assists the learners to distinguish, interpret, explore and be able to transform the world in which they live. It is thus concluded that teachers with poor backgrounds in English language are more likely to face a lot of problems when it comes to conveying the subject matter to learners even if the teacher is knowledgeable in the subject content.

\subsubsection{Marking Students' Assignments}

Marking students' assignments is one of the important elements of students' assessments. It makes students and teachers reach the expected and anticipated specific objectives in their lesson plans. Ogunniyi (1996) points out that marking students' assignments are activities designed to measure learners' achievements as a result of teaching and learning in a given program. He further adds that marking students' assignments is done because: it provides data about students learning and the data will provide feedback to the teacher and parents about how well the students are performing and it provides data about teacher's effectiveness.

The study revealed that the 26 out of 30 normal trained teachers frequently marked their students' assignments correctly and fairly and only 04 out of 30 normal train teachers did not frequently mark correctly and fairly. However 20 out of 30 licensed trained teachers did not mark their students' assignments frequently, correctly and fairly. Sometimes they took one week without marking students' assignments. However, 10 out of 30 licensed trained teachers frequently marked students' assignments accurately and fairly. It is thus obvious that normal trained teachers had more teaching effectiveness than licensed trained teachers.

5.2.7 Classroom Management Skills The classroom management skills constitute many factors which include: availability of teaching and learning materials, good methods of teaching, good mastery of the subject and language use and so on. Findings showed that 22 out of 30 licensed trained teachers did not demonstrate effective classroom management skills as compared to normal trained teachers because of the following reasons: First, they were not frequently using English language as medium of instruction all the time of teaching students compared to the normal trained teachers who used English language all the time of teaching. Second, they were rarely using teaching and learning materials and spent a lot of time talking to students. These situations, made students make noises throughout the teaching time because students were bored.

However, 24 out of 30 observed normal trained teachers demonstrated effective classroom management skills because they employed different methods of teaching, demonstrated masterly of language and used teaching and learning materials. Furthermore, all the 4 zonal secondary inspectorate officers and all 12 headmasters/mistresses interviewed pointed out that there was a difference in classroom management skills between licensed and normal trained teachers due to the fact that normal trained teachers were more frequently using different methods of teaching than licensed trained teachers.

In addition, 45 out 60 students reported the same views that licensed trained teachers' classroom management skills were poor compared to normal trained teachers who demonstrated good methods of teaching, good masterly of language use and teaching and learning materials. In this regard, it could be concluded that there was a difference in classroom management skills between licensed and normal trained teachers as Ogunniyi (1996) pointed out on the importance of classroom management skills to both teachers and students that it motivates learning processes.

\subsubsection{Methods of Teaching}

The findings of the study revealed that 12 out of 30 licensed trained teachers showed that they preferred group discussions, 8 preferred questions and answers, 6 preferred demonstrations and 4 preferred the inquiry method. On the other hand 13 out of 30 normal trained teachers preferred to use group discussions, 10 preferred to use questions and answers, 4 preferred to use demonstrations and 3 preferred the inquiry method. Both normal and licensed trained teachers had no difference in the preferences of the methods of teaching and learning. Other methods, such as experiment, case study, brain storming and lecture, were not used by any of the two types of teachers. The findings indicated that both types of teachers, to a large extent, preferred group discussions and questions and answers methods for teaching students in their classrooms. The zonal secondary schools inspectorate documentary 
reports also showed that both normal and licensed trained teachers preferred to use group discussion, questions and answers as well as demonstrations. 50 out 60 students and 9 out 12 headmasters/ mistresses revealed that both normal and licensed trained teachers preferred to use more group discussion and questions and answers than any other teaching methods. Table 2 below shows the methods of teaching used by both types of teachers teaching the same subject but in different classes.

Table 2: Methods of Teaching Applied by both Normal and Licensed Teachers.

\begin{tabular}{|c|c|c|c|c|c|c|c|c|c|c|}
\hline \multirow[b]{2}{*}{ 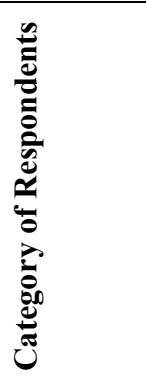 } & \multicolumn{10}{|c|}{ Methods of Teaching } \\
\hline & 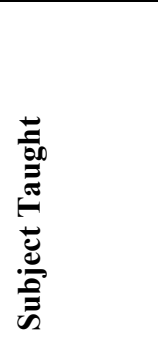 & 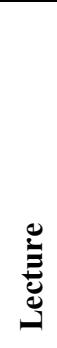 & 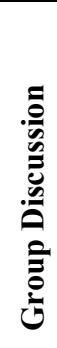 & 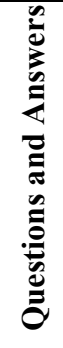 & 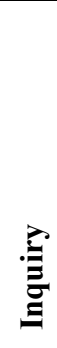 & 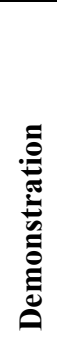 & & 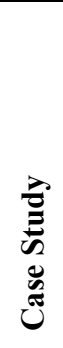 & 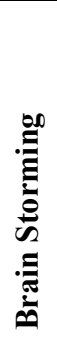 & 吾 \\
\hline $\begin{array}{l}\text { Licensed } \\
\text { Teachers }\end{array}$ & $\begin{array}{l}\text { History } \\
\text { Form IIIA }\end{array}$ & - & 12 & 08 & 04 & 06 & - & - & - & 30 \\
\hline $\begin{array}{l}\text { Normal } \\
\text { Teacher }\end{array}$ & $\begin{array}{l}\text { History } \\
\text { Form IIIB }\end{array}$ & - & 13 & 10 & 03 & 04 & - & - & - & 30 \\
\hline Students & $\begin{array}{l}\text { History } \\
\text { Form IIIB }\end{array}$ & - & 50 & 10 & - & - & - & - & - & 60 \\
\hline $\begin{array}{l}\text { Headmistr } \\
\text { ess/Head } \\
\text { master }\end{array}$ & $\begin{array}{l}\text { History } \\
\text { Form IIIA }\end{array}$ & - & 03 & 09 & - & - & - & - & - & 12 \\
\hline \multicolumn{2}{|l|}{ Total } & - & 78 & 37 & 07 & 10 & - & - & - & 132 \\
\hline
\end{tabular}

Source: Computed from field data (2014).

Table 2 above shows that there were no great differences in the use of methods of teaching between the two groups of teachers.

\subsubsection{Teacher Personality}

Findings from the study noted that 10 out of 12 headmasters/mistresses said that licensed trained teachers had poor personality compared to normal trained teachers. They argued that their dressing was not proper. Ladies dressed in mini-skirts while men were dressed in tight trousers. Moreover, all 4 zonal secondary schools inspectorate officers and 21 out of 24 students' parents said that licensed trained teachers dressed badly as compared to the normal trained teachers. The rest (3) of the students' parents did not see any difference in dressing and language use between the two types of teachers. Also the study observed that from all twelve visited secondary schools supported the headmasters'/ headmistresses' view of poor personality among the licensed trained teachers compared to normal trained teachers. This could be assumed that licensed trained teachers' personality was not as good as that of the normal trained teachers because they missed an important topic in their training program which is Guidance and Counselling. This topic was not taught to licensed trained teachers during their training due to shortage of time. These findings were similar to what Ogunniyi (1996) observed that, teachers always need to act and behave as models from whom people will appreciate and emulate.

\subsection{Conclusion}

The study found that there were significant disparities in teaching effectiveness between licensed and normal trained teachers. Normal trained teachers were more effective in teaching than licensed trained teachers. Normal trained teachers excelled than the licensed trained teachers in the following main areas; schemes of work, mastery of the subject matter and language use, teaching and learning materials, marking students' assignments and methods of teaching. On the other hand, licensed trained teachers were doing well in methods of teaching and attending inservice training compared to normal trained teachers.

\subsection{Recommendations}

In order to improve teaching effectiveness among the employed licensed trained teachers in general, the paper proposes the following recommendations; First, the MoEST should provide enough funds for teaching and learning materials. The availability of teaching and learning materials will simplify teaching and learning processes for both 
types of teachers in classrooms. The MoEST and other education stake-holders should construct enough classes, make desks and buy textbooks to schools so as to enable both licensed and normal trained teachers to have a conducive classroom environment. Secondly, the zonal and district secondary schools inspectorate officers should conduct frequent schools inspections in order to monitor the teachers in their day-to-day activities. This will enable both normal and licensed trained teachers to be serious with their teaching profession. Thirdly, the MoEST should provide and support general and specific in-service training programs, especially for the crash trained teachers, so that they become more knowledgeable and skilled in the teaching and learning processes. Fourth, school head masters/mistresses should see to it that daily routine of the teachers is monitored and that local arrangements are made for teachers to share knowledge and skills of teachers' behaviour among themselves. Also staff meetings could be used for exchanging views on teachers' personality and fifth, the Tanzania Institute of Education should ensure that schools curricula stay in operation for long duration of time before changing them. Wherever there is a need of changing the curricula, then, all education stake-holders including the teachers should be fully involved in the deliberations and when new curricula is introduced, then teachers should be oriented immediately on its use.

\subsection{References}

Campbell, J., kyriakides, I., Muijs, D and Robisson, W. (2004). Assessing Teacher Effectiveness: Developing a Differentiated Model, London: Routledge Falmer

Clandinin, J., (1995). Teachers' Professional Land Scales. New York: Lincoln Inc.

Galabawa, J. Senkoro, F and Lwaitama, F (2000). The Quality of Education in Tanzania. Dar es Salaam: Dar es Salaam University Press

Good, T, and Brophy, J. (2003). Looking in Classrooms $9^{\text {th }}$ edn, Boston: Pearson.

Hoy, J and Miskel, L (1991). Learning and Teaching Models. Chicago: Framer Press

Hudgins, B., (1971). The Instructional Process. Chicago: Rand McNally and Company.

Jones,J., Jenkin,M and Lord, S. (2006). Developing Effective Teacher Performance, London: Paul Chapman.

Libeman, M., (1956). Education as a Profession. Toronto: Prentice-Hall Inc.

Meli, B (2014). An Evaluation of Teacher Education and Training in Tanzania, Comparative Study between Licensed and Normal Trained Teachers, A PhD thesis Submitted to University of Dar es Salaam

Middlewood, D. And Cardno, C.E. (2001). Managing Teacher Appraisal and Performance, London: Routledge Palmer

Ministry of Education, Vocation and Training (2004). Education System in Tanzania Towards the Year 2000, Dar es Salaam, Government Printers

Mussika, E., (2002). Teachers Training and the Classroom Performance of Grade IIIA Teachers in Tanzania. Unpublished M.A (Ed) Dissertation. Faculty of Education, University of Dar es Salaam.

Ogunniyi, M., (1996). Educational Measurement and Evaluation. Lagos: Longman Nigerian Ltd.

Osaki, K., (1996). 'The Challenging Forms, Content and Interpretation of Curriculum in Tanzania'. Papers in Education and Development. Vol. -. No 17. pp. 8-19.

Petty, G. (2006). Evidence Based Teaching: A Practical Approach. Cheltenham: Nelson Thornes

Pollard, A with Anderson, J, Maddock, M., Swaffield, S., Warin, J. And Warick, P. (2008). Reflective Teaching: Evidence -informed Professional Practice $3^{\text {rd }}$ edn, London: Continuum.

Sahlberg, P., (2003). Practical Teachers' Guide: Learning and Teaching Enrichment in Tanzania Schools. Mimeograph: Dar es Salaam.

Stronge, J, H. (2007). Qualities of Effective Teachers $2^{\text {nd }}$ edn, Alexandria, Virginia: Association for Supervision and Curriculum Development

Trowbridge, L., and Bybee, R., (1996). Teaching Secondary Schools: Strategies for Developing Scientific Literacy. Columbus: Merrill Publishing Company.

United Republic of Tanzania, (2001-2008). Basic Statistics with Education. Dar es Salaam: Kiuta. 